\title{
Book Review: Neoliberalism's War on Higher Education
}

\author{
Edited by Henry A. Giroux \\ Chicago: Haymarket Books, 2014. 240 pp. \\ ISBN: 978-16-084-6334-3.
}

Henry A. Giroux, an established professor of education, who currently holds the Global Television Network Chair in English and Cultural Studies at McMaster University, warns readers about the pitfalls of a market-driven educational approach to higher education. As a champion of higher education, Giroux argues that institutions need to be protected as a source of critical learning and democratic promise for students and the community. As such, he calls for a critical reevaluation of pedagogy in order to harvest an effective, yet responsible, field of higher education.

Arguing for a moral and political refocus in higher education, Henry A. Giroux wrote Neoliberalism's War on Higher Education as a call to action in response to the socio-political constraints placed upon the field of higher education, urging practitioners to push against the movement as it is threatening the existence of the higher education system in America. Although functioning as a critique of social constructs, Giroux's work offers a hint of optimism as it pertains to the future of higher education - encouraging practitioners, researchers, and advocates of higher education alike to reevaluate their actions as they relate to democratic participation through this exploration of current issues surrounding institutions of higher learning and responsible citizenship.

The first chapter of this book focuses on the positioning of higher education in our current "neoliberal" society. Giroux argues that society's focus on standardized testing and skill-based instruction is leading to the destruction of education, as the format has shifted from a critical approach to a conformity model that ultimately represses students. Within such an environment, schools become "simply another corporate asset bundled in credit default swaps" (p. 29). Therefore, Giroux is critical of today's educational model as it is centered on corporate values and power dynamics. The author argues that the focus should rather be centered on students' education and their ability to become engaged and active citizens. This chapter focuses on the politicization and the corporatization of education, highlighting critical areas of concern from student evaluation methods to pedagogical issues. Consequently, Giroux calls educators to rally against this damaging “dystopian” pedagogy (pp. 30-31).

The second chapter promotes resistance to social commercialization - particularly in education - though, deemphasizing public wealth and reemphasizing issues concerning community and the public good. Giroux argues that in today's society, "higher education matters only to the extent that it promotes natural prosperity and drives economic growth, innovation, and transformation" (p. 58), and points to issues in England and the United States surrounding funding concerns, tuition increases, and the decline of critical thinking skill attainment in students as examples of market-driven education. In opposition to this trend, he depicts London's students' protest against governmental cuts, as well as American's involvement in the Occupy Wall Street movement. Giroux sees modern student protests as an attack of higher education's current position as well as the greater issue of "casino capitalism". In this sense, these protests serve as an outlet for discussion, bringing awareness to the issues a market approach to education has created and thus uses this chapter to mark the importance of connecting learning to social change.

The overall pedagogical issues surrounding higher education are discussed in Chapter 3, specifically focusing on what Giroux has termed, "intellectual violence" (pp. 81-83). Giroux uses this chapter to articulate his concern regarding said violence connected to "neoliberal deceit" (p. 81) present in the power relations within modern society. Therefore, this type of violence is not typical physical violence, but rather violence in the sense that it limits society's potential to grow and develop. Giroux argues that the politics surrounding education and funding squelch opportunities for growth and success in the field, thus thwarting opportunities for students as well. In this sense, violence imposes a uniform truth on society, ultimately eliminating the chance for 
critical debate to occur - therefore fostering a uniform, passive society that is rehearsed and void of true substance.

Chapter 4 describes the extreme ways in which institutions are collapsing due to the issues surrounding our society. Giroux uses large-scale scandals, such as the Penn State/Sandusky sexual abuse scandal, to discuss neoliberalism's attack on education as a democratic system. The author argues that such scandals exemplify an institutional lack of concern and social responsibility, as academic missions are abandoned in an attempt to focus on market concerns. This chapter argues that the Penn State scandal was more than a case of sexual abuse, it was also a "tragic narrative" about an institution using its money and power to "cover up complicity" in crimes in order to protect their "power, influence and brand" in order to maintain sponsorships, enrollments, and prestigious staff appointments (p. 108). Giroux considers this situation a moral and ethical crisis that affects individuals' integrity as well as the overall success of institutions. The author even goes so far to say that this crisis has presented itself as an attack on democracy (p. 124). Therefore, this chapter serves to urge educators to learn from the Penn State scandal- to push for a true democratic society and political vision for education.

The final two chapters serve as a call to community members to rally on behalf of higher education, providing the example of the student movement in Quebec. Giroux views academics as "public intellectuals," responsible for protecting the purpose and meaning of education in a society becoming increasingly focused on labor. In this sense, the author calls for educators to foster growth opportunities in students that will produce "critical citizens rather than potential employees of Walmart" (p. 137). Giroux, in calling for active stances against the current state of education, provides examples of youth working to redefine education - speaking out against policies and procedures that take away from the founding principles of institutions, highlighting the student protest movement in Quebec, which was sparked out of a drastic tuition fee increase in March of 2011. In particular, Giroux uses this example to inform readers of the passion instilled in college students for change. More generally, this example speaks to the power of open discussion and raising awareness to facilitate social transformation.

The book concludes with an interview between the author and Michael A. Peters, which effectively situates Giroux's views within a broader historical discussion of his previous works surrounding culture, politics, and higher education. This conversation works to bring to light the author's struggles in working against the powerful political system of higher education in an effort to provide a sense of camaraderie with other struggling professionals while also offering encouragement-as
Giroux's story offers exemplars of initiatives where social change was made possible.

While Neoliberalism's War on Education speaks, in no uncertain terms, about the critical condition of today's educational system, it optimistically encourages educators to take ownership of the system. Giroux describes higher education as "one of the most important institutions in which a country's commitment to young people can be made visible and concrete" (p. 129). The reflection and commitment to change that is discussed throughout the work, showcases the author's opinion that there is a possibility of realignment, and ultimately, success for the field of higher education. In this sense, Giroux views America's system of higher education as one of the few places left with a true ability to nurture individuals, instill value and hope in society, and also generate a substantive democracy (p. 140).

Overall, this book is helpful for those researching the systemic issues of the current higher education system crisis. Practitioners and academics looking to explore the impact of modern day politics on public realms such as higher education will have the opportunity to utilize Giroux's argument as a frame to critique contemporary American society. Unfortunately, individuals looking for solutions or potential remedies to the discussed problems and concerns will be disappointed as Giroux offers no silver bullet, or even practical suggestions for action against said issues. However, he does provide a venue for individuals interested in the field to begin to think about the field's significant concerns. While a somewhat brash, and some would argue sensationalized, discussion of neoliberalism - as the author speaks powerfully about modern day injustices he sees towards the American educational system - this piece serves as a well-crafted critique that challenges readers to think about critical and timely issues within the higher education sector.

Reviewed by Jessica Lynn Mann University of Pittsburgh, USA 